\author{
С.К. Уалиева ${ }^{1}$ \\ ${ }^{l}$ к.и.н., доиент Восточно-Казахстанского государственного \\ технического университета им. Д. Серикбаева, \\ 2. Усть-Каменогорск, Казахстан
}

\title{
НОВЫЕ ОСОБЕННОСТИ В ФОРМИРОВАНИИ ЭТНИЧЕСКОЙ ИДЕНТИЧНОСТИ ДЕТЕЙ ИЗ МЕЖЭТНИЧЕСКИХ БРАКОВ В ВОСТОЧНОМ КАЗАХСТАНЕ
}

\section{Аннотачия}

В современном Казахстане вопросы этнической идентичности детей из смешанных браков вызывают особый интерес, поскольку за прошедшие годы изменения в общественно-политической жизни вызвали перемены в сознании молодых людей.

В данной статье рассмотрены некоторые вопросы этнической идентификации и самоидентификации детей из межэтнических браков. Выявлены новые особенности в формировании этнической идентичности. Если десятилетием раньше, молодые люди из межэтнических браков - по самоопределению были русскоговорящими и ближе к русскоязычной среде, вне зависимости от записи в документах казахами. В настоящее время - современные молодые люди смешанного происхождения определяют себя казахами, вне зависимости от того, что записаны по документам русскими, немцами.

Причины таких разительных изменений в постепенном изменении общественнополитической и культурной составляющей нашего общества. Больший акцент на казахском языке обучения для метисов, родители связывают с осознанием будущего детей, их успешности в обществе.

Ключевые слова: этническая идентичность, межэтнические браки, самоидентификация, метис, культура, менталитет, самоопределение.

\author{
С.К. Уалиева ${ }^{l}$ \\ ${ }^{1}$ т.в.к., Д.Серікбаев атындавы Шызыс Қазақстан мемлекеттік \\ техникальқ университетінің доценты, \\ Өскемен ку., Қазақсттан
}

\section{ШЫҒЫС ҚАЗАҚСТАНДАҒЫ ЭТНОСАРАЛЫК НЕКЕЛЕРДЕН ШЫҚҚАН БАЛАЛАРДЫН ЭТНИКАЛЫҚ БІРЕГЕЙЛІК ҚАЛЫПТАСТЫРУДАҒЫ ЖАНА ЕРЕКШЕЛІКТЕРІ}

\section{Aң̧датпа}

Қазіргі Қазақстанда аралас некелерден шыққан балалардың этникалық ұқсастығы мәселелері ерекше қызығушылық тудырады, өйткені өткен жылдар ішінде қоғамдық-саяси өмірдегі өзгерістер жас адамдардың санасындағы өзгерістерді тудырды.

Бұл мақалада этносаралық некеден шыққан балалардың этникалық сәйкестендіру және өзінөзі сәйкестендіру мәселелері қарастырылған. Этникалық бірегейлікті қалыптастырудағы жаңа ерекшеліктер анықталды. Онжылдықтар бұрын этникааралық некеден шыққан жастар құжатта қазақ болғанымен, өзін-өзі анықтау бойынша орыс тілді немесе орыс тілді ортаға жақын болды. Қазіргі уақытта аралас текті жастар құжаттары бойынша орыс, неміс деп жазылуына қарамастан, өздерін қазақ деп анықтайды.

Бұндай айрықша өзгерістердің себебі елдің қоғамдық-саяси және мәдени құрамдас бөлігінің біртіндеп өзгеруіне байланысты. Метистерді қазақ тілінде оқытуға көп көңілді ата-аналары бөлуде, және оны балаларының болашағы мен олардың қоғамдағы табыстылығыменн байланыстырады.

Түйін сөздер: этникалық бірегейлік, этносаралық неке, өзін-өзі тану, метис, мәдениет, менталитет, өзін-өзі анықтау.

$$
\text { Ualiyeva S.K. }{ }^{l}
$$




\section{${ }^{1}$ Candidate of Historical Sciences Associate professor of the D. Serikbayev \\ East Kazakhstan State Technical University, \\ Ust-Kamenogorsk, Kazakhstan}

\section{NEW FEATURES IN THE FORMATION OF ETHNIC IDENTITY OF CHILDREN FROM INTER-ETHNIC MARRIAGES IN EARSTERN KAZAKHSTAN}

Abstract
In Kazakhstan today, the ethnic identity of children from mixed marriages is of particular interest, as changes in social and political life have brought new changes in the minds of young people over the years.

This article addresses some of the issues of ethnic identification and self-identification of children from inter-ethnic marriages. New features in the formation of ethnic identity have been identified. If a decade earlier, young people from inter-ethnic marriages - by self-determination - were Russian-speaking and closer to the Russian-speaking environment, regardless of the entry in the documents of the Kazakhs. Nowadays - modern young people of mixed origin define themselves as Kazakhs, regardless of what is written on documents by Russians and Germans.

The reasons for such interesting changes are in the gradually changing of socio-political and cultural situation of our society. Greater emphasis on the Kazakh language of education for mestizos, parents linked to the awareness of the future of children and their success in society.

Key words: ethnic identity, inter-ethnic marriage, self-identification, mestizo, culture, mentality, self-determination.

Идентификация детей от смешанных браков представляет особый интерес для исследований. Для молодых людей, смешанного этнического происхождения, особое значение имеют вопросы, касающиеся определения их этнической идентичности. В соответствии с законодательством Республики Казахстан, молодые люди при получении документов, имеют право выбирать этническую принадлежность одного из родителей, или оставлять прочерк в графе. В то же время, определение этнической идентичности не является однодневным решением, и такие вопросы могут вызывать озабоченность на протяжении всей жизни. Первыми оказывают влияние родители, ближайший круг контактов, социальная среда молодых людей.

Существует ряд научных подходов к понятию этническая идентичность:

1) это осознание человеком своей принадлежности к определенной этнической общности, принятие им определенных групповых представлений, готовность к сходному образу мыслей и разделяемые этнические чувства. [1]

2) это когнитивный процесс объединения субъектом себя с другими представителями одной с ним этнической группы, а также его позитивное ценностное отношение к истории, культуре, национальным традициям и обычаям своего народа, к его идеалам, чувствам и интересам, фольклору и языку, территории проживания этноса и его государственности. [2]

3) В психологии этническая идентичность рассматривается как одна из черт личности, являющейся социальной по своим последствиям. Этническая идентичность - это осознание своей принадлежности к определенной этнической общности и обособления от других этносов. Этническая идентичность - это переживание своего тождества с одной этнической общностью и отделения от других. Этничность определяется по ряду объективных показателей: этнической принадлежности родителей, месту рождения, языку, культуре [3].

Люди лучше всего осознают свою этническую самобытность в процессе межэтнического общения и в многокультурной среде. Этот аспект особенно важен в случае межэтнических браков. Не четко выраженная идентичность личности или даже ее отсутствие в некоторых случаях могут быть понятны. Нас интересует, как в межэтнической семье формируется этническая идентичность.

Специальные социологические исследования в этой области позволяют конкретно изучить этническую идентичность лиц смешанного происхождения.

В данной статье представлены исследования: новые материалы глубинных интервью по теме исследования: «Межэтнические браки в Казахстане», а так же сравнение с результатами предыдущих исследований по теме [4]. Поскольку межнациональная семья предполагает различную этническую принадлежность родителей, ребенок объективно вовлечен в ситуацию межэтнического взаимодействия в рамках одной и той же семьи. 
Межэтнические браки сами по себе носят многокультурный характер, являясь результатом сотрудничества этнических групп в рамках одной семьи. Все это может иметь последствия для идентификации этничности детей в рамках семьи, где смешиваются различные этнические культуры и религии.

Изучение вопроса о воспроизводстве этнической самобытности свидетельствует об актуальности терпимости в обществе для лиц смешанного происхождения. В этом контексте вопросы самоидентификации лиц смешанного происхождения создают возможности для свободного выбора и воспроизводства идентичности в определенном государстве.

Результаты наших интервью показывают, насколько различен процесс идентификации личности лицами смешанного происхождения в современном Казахстане. Дети от межэтнических браков являются более открытыми и терпимыми к различным культурам. Лица смешанного происхождения из таких семей сами чаще называют себя метисами. Внешний вид этих детей отличен, что влияет на самоидентификацию по-разному.

В случае этнической самоидентификации детей от межэтнических браков внешние данные не играют первостепенной роли и не играют доминирующей роли. Имя, фамилия и отчество также не являются определяющими признаками этнической принадлежности. Наши беседы показывают, что дети из смешанных семей выбирали этническую принадлежность в большинстве случаев по отцу, при получении документов [4].

Следует отметить ряд интервью, в ходе которых респонденты не испытывали никаких сомнений в отношении определения этнической принадлежности. В этом случае определенную роль играют как воспитание, так и условия, влияющие на выбор.

Однако ответы на вопрос: «Как вы чувствуете, к какой этнической группе вы относитесь?» во многих случаях были не столь однозначными. В действительности этническая самоидентификация детей, рожденных в межэтнических браках, часто отличается от документированной. Иными словами, этническая принадлежность и самоидентификация лиц из де-юре и де-факто, из межэтнических браков не совпадают. Влияние имеет различные причины. В целом, процесс социализации имеет важное значение - отношения внутри семьи, круг общения, друзья, родственники и влияние общества в целом.

Дети из одной семьи могут идентифицировать себя по-разному: по отцу и по матери. В материалах 2008 года в межэтнических браках, респондент под псевдоним «Дарья Ким» [4], 58 лет, (украинка, муж кореец), старшая дочь в документах зарегистрирована как кореянка, также как отец. А младшая дочь выбрала национальность матери - украинка. Обе дочери выглядят как люди смешанного происхождения.

В материалах 2018 года из интервью Мария Леонова [5], 41 год, вышла замуж за казаха. Разговор состоялся в 2018 году, младший сын Тимур, 7 лет, спросил мать: «Нурсултан Назарбаев, президент страны, кто по национальности?» Мать ответила: «Казах». Тимур затем заявил, что он тоже казах, как и президент. Старший сын Руслан, 11 лет, спросил свою мать о президенте Путине, какова его национальность. И сказал, что он как Путин, русский. Это, конечно, на первый взгляд детский разговор, но в контексте смешанной семьи он дает особое представление о том, как социальная и политическая жизнь влияет на идентификацию детей из одной и той же семьи.

В материалах, собранных нами в 2008-2009 годах [4], в значительно большей степени молодые люди смешанного происхождения говорили на русском языке, а их культура и менталитет, независимо от того, что они были записаны в документах как казахи по отцу, характеризовалась как русская. Следует отметить, что наше внимание сосредоточено на браках между тюркскими и славянскими этносами. Сами молодые люди называют себя метисами.

Пример из интервью респондента Тимура Бейсембаева, 20 лет: Я из интернациональной семьи, папа казах, мама русская. Бабушка (мать папы) обрадовалась, когда в документе я записался казах. В плане выбора - было просто, выбирай что хочешь. Принципиального значения не было ни со стороны мамы, ни со стороны отца. Я подумал, что со стороны отца возьму национальность. И взял со стороны отца - казах. Так свободно, даже долго не раздумывая. Мама нормально отнеслась. Теперь в семье два казаха. Я и отец»» [4]. После окончания университета в г. Усть-Каменогорске, Тимур продолжил обучение в магистратуре в российском высшем учебном заведении и отметил, что ему комфортно жить в новой среде.

Тимур Жампеисов, 25 лет, смешанного происхождения, отец казах, мать - русская, заявил в интервью: «Вопроса с выбором национальности не возникало. Как продолжатель рода, по мужской линии выбор был предопределен, и сомнений не было. По национальной 
принадлежности я считаю себя казахом» [4]. Позже Тимур женился на русской девушке, у них хорошая семья и двое детей.

В отношении этнической самоидентификации Руслан Кимасов, 19 лет, смешанного русскоказахского происхождения, зарегистрированный в документах русским как его отец, отметил: «Я привык не идентифицировать себя ни с русскими, ни с казахами. Мне от этого больно, что ли... Я ущемляю права мамы или папы на мою национальную принадлежность. С другой стороны, глобальных проблем не возникало, так как я думаю на русском, разговариваю на русском, но так как я живу в Казахстане и из-за моей внешности, то и к казахам у меня хорошее отношение. Я как бы на стыке двух культур» [4].

Из беседы с респондентом Анной Нугумановой, 21 год: «Я метиска. Папа казах, мама русская. В документах записана казашка. Все же я отличаюсь. Я говорю - я метиска. Мне нравится, что я метиска. Хочешь - и казашка, и хочешь - русская〉 [4].

Следует подчеркнуть, что как Тимур, так и Руслан, и Анна - больше отождествляют себя с русской культурой, а знания казахского языка практически отсутствовали у всех респондентов смешанного происхождения, с которыми мы беседовали десять лет назад. Хотя некоторые респонденты были зарегистрированы казахами по документам, в действительности чувства были смешанными и все они были русскоязычными. И выбор брачных партнеров позже, и круг общения, оказался русским, или метисы, как и они сами.

В последнее время в нашем регионе наметились новые противоположные тенденции в формировании идентичности детей от межэтнических браков. Интересной особенностью является обучение на казахском языке молодежи смешанного происхождения, что, несомненно, влияет на выбор идентичности, самосознания и формирование менталитета. По документам, эти молодые люди зарегистрированы русскими или немцами.

Воронин Руслан Павлович [6], 20 лет, отец русский, мать казашка, уроженец г. Шар. Последние четыре года жил в г. Семипалатинске. Учился в школе, колледже, университете на казахском языке, говорит по-русски с акцентом, и самоопределение этнической идентичности казах. Руслан отмечает: «Друзья все казахи, больше себя чувствую казахом, хотя по документам русский. На казахском языке мне легче общаться».

Артем Владимирович Рожинский [7], 17 лет, отец немец, мать казашка, родом из с. Кайынды, Курчумского района. В вузе он обучается на казахском языке. Он говорит по-русски с небольшим акцентом. Самоидентификация Артема - что он является метисом, согласно документам (удостоверению личности), зарегистрирован как отец - немец. В интервью выясняется, что были родители, когда он получал документ, и они шутили, что возможно, как маму запишут казахом и сына. Сам Артем четко определил, что будет записан немцем, как и отец. Среда и круг общения Артема в основном говорящие на казахском языке.

В рекомендациях от родных на ком женится, Артем отмечает: «Бабушка со стороны отца говорит - женись на русской, она и сама русская. Бабушка еще говорит по-казахски. А папа советует - женись на том, кого любишь». Из интервью с Артемом: «если честно, я хочу на немке женится, чтобы и дальше дети были метисы, родня разная. Есть желание побывать в Германии, где живут родственники со стороны отца. Хочу немецкий язык выучить тоже» [7].

Граменский Руслан [8], 18 лет, г. Семипалатинск, родители: у отца в роду поляки, немцы (с Западной Украины), мама казашка. Ясно видит свою отличность, ему это нравится. Самоощущения по самоидентификации это метис, хотя по документам записан казах (удостоверение личности).

Материалы вышеупомянутых опросов показывают, в какой степени концепция «метис» присутствует в самосознании респондентов. Им легче определить свою идентичность таким образом.

За последнее десятилетие среди молодежи из этнически смешанных семей наметились новые тенденции. Согласно опросам, проведенным в 2008-2009 годах, двадцатилетние молодые люди в основном говорили и обучались на русском языке, и, следовательно, культура и окружающая среда были русскоязычными. Десять лет спустя новые молодые люди смешанного происхождения уже обучаются на казахском языке, говорят по-русски с акцентом, а культурная среда в основном казахоязычная.

С точки зрения самоидентификации эти молодые люди по-прежнему относят себя к метисам, поскольку они знают о своем смешанном происхождении, и это также находит свое отражение в имени, фамилии и отчестве молодых людей. Они воспринимают свою особенность как особый 
актив и считают это определенным преимуществом. Конечно, в группах с казахским языком обучения фамилии Воронин, Граменский и Рожинский звучат необычно.

Новая тенденция существенно отличается от предыдущих лет, когда молодые люди смешанного происхождения получали образование и говорили по-русски, что в большей степени учитывалось в семейном окружении таких семей. Причины таких разительных изменений и в постепенном изменении социально-политической и культурной структуры нашего общества. Большее внимание казахскому языку обучения для метисов, родители связывают с осознанием будущего детей и их успешности в обществе.

В целом, изменения в общественном сознании оказывают неоспоримое воздействие на культуру, язык и самоидентификацию молодых людей из межэтнических браков. Изучение результатов конкретных социологических исследований подтверждает, что процесс самоопределения этнической идентичности лиц смешанного происхождения процесс неоднозначный.

\section{Список использованной литературы:}

1. http://www.edu-resourse.asia/glossariy-2/

2. Этнопсихологический словарь. - М.: МПСИ. В.Г. Крысько. 1999.

3. Султанбаева К.И. Курс лекиий по дисииплине этнопедагогика и этнопсихология. - Абакан, 2010.

4. Уалиева С.К. «Этническая идентичность людей межэтнического происхождения в Казахстане» // «Вестник КазНПУ им. Абая», серия Исторические и сочиально-политические науки, №2 (53), 2017. - стр. 159-164.

5. Интервью: Мария Леонова, ноябрь 2018.

6. Интервью: Руслан Воронин, ноябрь 2017.

7. Интервью: Артем Рожинский, сентябрь 2019.

8. Интервью: Руслан Граменский, сентябрь 2019.

1. http://www.edu-resourse.asia/glossariy-2/

\section{References:}

2. Ethnopsychological dictionary. - M.: MPSI. V. G. Krysko. 1999.

3. Sultanbayeva K. I. Course of lectures on the discipline of ethnopedagogy and ethnopsychology. Abakan, 2010.

4. Ualieva S. K. "Ethnic identity of people of interethnic origin in Kazakhstan "//" Vestnik KazNPU im. Abaya", a series of Historical and socio-political sciences, №2 (53), 2017. - pp. 159-164.

5. Interview: Maria Leonova, November 2018.

6. Interview: Ruslan Voronin, November 2017.

7. Interview: Artem Rozhinsky, September 2019.

8. Interview: Ruslan Gramensky, September 2019. 